\title{
Optimization of Lateral Depth of Subsurface Drip Fertigation for Amaranthus
}

\author{
S. Sariga*, Jeena Joseph and Priya G. Nair \\ Kerala Agricultural University, Kerala, India \\ *Corresponding author
}

\begin{tabular}{|l|}
\hline Ke y w o r d s \\
$\begin{array}{l}\text { Fertigation, Lateral } \\
\text { depths, Subsurface } \\
\text { irrigation, Plastic } \\
\text { mulching }\end{array}$ \\
\hline Article Info \\
\hline $\begin{array}{l}\text { Accepted: } \\
\text { 07 June 2019 } \\
\text { Available Online: } \\
\text { 10 July } 2019\end{array}$ \\
\hline
\end{tabular}

\section{A B S T R A C T}

The main concept of drip irrigation is to create a continuous wetted strip directly beneath the soil where the active roots are concentrated. The fertigation allows application of right amounts of plant nutrients uniformly to the wetted root zone. A field experiment was conducted to evaluate the effect of different fertigation levels and depth of laterals under plastic mulch on the performance of Amaranthus (Amaranthus hypochondriacu, variety: kannara local). The yield showed significant difference with different levels of fertigation and depth of laterals. Based on the statistical analysis the study suggested that treatment of $80 \%$ fertigation and $10 \mathrm{~cm}$ lateral depth is better due to the fact that it gives higher crop yields (7.2 t/ha) with substantial saving in fertilizer usage. Hence, subsurface drip irrigation of $10 \mathrm{~cm}$ lateral depth with $80 \%$ fertigation level under plastic mulching for amaranthus is a good option.

\section{Introduction}

The micro irrigation system is one of the most efficient methods of water application directly into soil at the root zone of plants. Micro irrigation includes mainly drip and micro sprinklers are an effective tool for conserving water resources. It is an irrigation system with high frequency application of water in and around the root zone of plant system, which consists of a network of pipes along with suitable emitting devices. It permits a small uniform flow of water at a constant discharge, which does not change significantly throughout the field. It also permits the irrigation to limit the watering closely to the consumptive use of plants. Thus it minimizes the conventional losses such as deep percolation, runoff and soil evaporation. It also permits the utilization of fertilizer, pesticides and other water-soluble chemicals along with irrigation water for better crop response. Fertigation is the application of fertilizers, soil amendments, or other watersoluble products through an irrigation system. Benefits of fertigation over traditional broadcast or drop-fertilizing methods include: increased nutrient absorption by plants, 
reduction in fertilizer and chemicals needed, reduced leaching to the water table, reduction in water usage due to the plant's resulting increased root mass's ability to trap and hold water, application of nutrients at the precise time they are needed and at the rate they are utilized. The important components of a fertigation system include drip irrigation system of suitable layout and fertigation equipment. During summer season, the available water has to be used effectively and the soil moisture has to be conserved. Mulching is a relevant practice for soil moisture conservation under this context. Fertigation along with mulching helps to achieve both the objectives of efficient utilization of available water and the conservation of soil moisture.

Plastic mulch can reduce the loss of soil moisture. Effective control of weed growth is also attained under this system. Since micro irrigation greatly enhances water, fertilizer and energy use efficiency, the sustainability in agriculture could be achieved without the burden of environmental degradation. This study has undertaken to optimize the fertigation level and depth of laterals under subsurface drip irrigation for amaranthus.

\section{Materials and Methods}

The experiment was conducted at the Instructional Farm, Kelappaji College of Agricultural Engineering and Technology (KCAET), Malappuram, Kerala during the period of October 2012 to January 2013. In this study, low density polyethylene pipe of $16 \mathrm{~mm}$ diameter was used as the laterals which were provided with individual tap to control the flow rate and end caps are provided at the end of laterals and inline drippers of 4liters per hour discharge with a spacing of $40 \mathrm{~cm}$ were used and a dosmatic fertigation unit was used for fertigation.

\section{Treatment details and Installation of drip system}

Total ten treatments were laid out for the experiment, from which nine treatments are the combination consisting of three fertigation levels and three depths of laterals and one treatment as control were shown in Table 1 and the ten treatment was replicated thrice. A pump of $4 \mathrm{hp}$ was used for this study. Two pressure gauges with pressure range of $0-7 \mathrm{~kg}$ (f) $/ \mathrm{cm}^{2}$ were located before and after the fertigation unit for indicating the pressure in the system. PVC pipes of $90 \mathrm{~mm}$ and $75 \mathrm{~mm}$ diameter with pressure rating of $6 \mathrm{~kg}(\mathrm{f}) / \mathrm{cm}^{2}$ was used as the main and sub main respectively.

Raised beds of size $12 \times 0.9 \mathrm{~m}^{2}$ of 30 numbers were taken and in between two beds a spacing of $15 \mathrm{~cm}$ was given. The laterals were placed at three different depths of 10,20 and $30 \mathrm{~cm}$ below the soil surface. Black plastic mulch (12m length and width of $1.2 \mathrm{~m}$ ) sheet of 30 micron was used for covering the soil and holes of $10 \mathrm{~cm}$ diameter were punched evenly at $40 \mathrm{~cm} \times 40 \mathrm{~cm}$ grid points on the LDPE sheets.

\section{Spacing and Transplanting of Amaranth}

In this study Amaranth (Amaranthus spp.) variety kannara local was chosen as an experimental plant. A spacing of $40 \times 40 \mathrm{~cm}^{2}$, recommended for amaranthus in the Package of practices recommendations: Crops (KAU, 2005) was adopted. This variety requires the water requirement of about 21/day/plant.

Seeds were sown in the prepared soil bed of $8 \times 1 \mathrm{~m}^{2}$ with a seed rate of $4.2 \mathrm{gm} / \mathrm{m}^{2}$ and two week old seedlings were transplanted to the main field. In the mulched plots seedlings were then planted in the holes. The transplanting was done at a spacing of $40 \mathrm{~cm} \times 40 \mathrm{~cm}$ with 60 plants in each plot. 


\section{Fertilizer application}

For amaranth crop the recommended dose of fertilizer requirement was $50: 50: 50 \mathrm{~kg} / \mathrm{ha}$ (KAU, 2005) fertilizer was applied as per treatments in sixteen equal splits at four days interval. Nitrogen, phosphorus and potassium were the main nutrients required for the growth and these was applied Rajphos as a basal dose, urea, multi $\mathrm{K}$ and polyfeed (19:19:19) through dosmatic fertigation unit except control unit from five week to thirteenth week after planting. The recommended dose of fertizer for control treatment was applied to the base of the plant. Fertilizer requirement for different treatments were shown in Table 2.

\section{Experimental data}

Three plants were selected randomly from the net plot area in each treatment and were tagged to record the variations. The average girth and numbers of leaves of the randomly selected plants grown under each treatment was taken in a weekly interval and the observation was first taken two weeks after planting.

The first yield $(\mathrm{kg} / \mathrm{ha})$ was taken one month after transplanting. After the first harvest, other harvests were done at an interval of 7 days. The total of the seven harvests were taken.

Statistical analysis was done by analysis of variance (ANOVA). Analysis was compared between the treatments.

\section{Results and Discussion}

The following results obtained from the study were analyzed to provide basic information of different fertigation level and depth under subsurface drip irrigation and its performance on growth and yield of crop.

\section{Number of leaves}

The readings of number of leaves are shown in Table 3. The maximum number of leaves was observed for the treatment $100 \%$ fertigation with $10 \mathrm{~cm}$ lateral depth and minimum was seen in control. In case of fertigation, it was observed that maximum fertilizer utilization is at a depth of $10 \mathrm{~cm}$. This clearly indicates that, for different fertigation levels, more extraction of fertilizer can be seen in $10 \mathrm{~cm}$ depth compared to 20 and $30 \mathrm{~cm}$ depths. But there were no significant variations in number of leaves in other treatments i.e., with 20 and $30 \mathrm{~cm}$ depths Kant and Naoi (1998) also reported the similar results.

\section{Stem girth}

The readings (Table 4) were taken upto 7 week after transplanting. The maximum value obtained $(5.6 \mathrm{~cm})$ in the case of stem girth was observed for the treatment $100 \%$ fertigation level and $10 \mathrm{~cm}$ lateral depth. From the first observation onwards, it is clearly seen that maximum stem girth was observed in case of treatment is having $100 \%$ fertigation level and $10 \mathrm{~cm}$ lateral depth. The minimum value $(4.2$ $\mathrm{cm}$ ) is seen for the treatment $100 \%$ fertigation level and $30 \mathrm{~cm}$ lateral depth. The control treatment shows $4.4 \mathrm{~cm}$ stem girth. The statistical analysis shows that the stem girth at different days after planting did not differ significantly with respect to the different treatments (Reddy et al., 2005). The analysis also shows that for the stem girth, there was no significant difference in between replications and treatments.

\section{Yield of amaranthus}

In the first harvest at 30days after planting, the high yield $(0.6 \mathrm{t} / \mathrm{ha})$ was observed for treatment $100 \%$ fertigation with $10 \mathrm{~cm}$ lateral and the plants in the control plot were not matured enough to harvest. 
Table.1 Treatment details

\begin{tabular}{|c|l|}
\hline Treatments & Description \\
\hline T1 & 120\% of fertigation level, lateral of $4 \mathrm{l} / \mathrm{h}$ at $10 \mathrm{~cm}$ depth \\
\hline T2 & 100\% of fertigation level, lateral of $4 \mathrm{l} / \mathrm{h}$ at $10 \mathrm{~cm}$ depth \\
\hline T3 & 80\% of fertigation level, lateral of $4 \mathrm{l} / \mathrm{h}$ at $10 \mathrm{~cm}$ depth \\
\hline T4 & $120 \%$ of fertigation level, lateral of $4 \mathrm{l} / \mathrm{h}$ at $20 \mathrm{~cm}$ depth \\
\hline T5 & $100 \%$ of fertigation level, lateral of $4 \mathrm{l} / \mathrm{h}$ at $20 \mathrm{~cm}$ depth \\
\hline T6 & $80 \%$ of fertigation level, lateral of $4 \mathrm{l} / \mathrm{h}$ at $20 \mathrm{~cm}$ depth \\
\hline T7 & $120 \%$ of fertigation level, lateral of $4 \mathrm{l} / \mathrm{h}$ at $30 \mathrm{~cm}$ depth \\
\hline T8 & $100 \%$ of fertigation level, lateral of $4 \mathrm{l} / \mathrm{h}$ at $30 \mathrm{~cm}$ depth \\
\hline T9 & $80 \%$ of fertigation level, lateral of $4 \mathrm{l} / \mathrm{h}$ at $30 \mathrm{~cm} \mathrm{depth}$ \\
\hline C & Control \\
\hline
\end{tabular}

Table.2 Fertilizer requirement per bed (Recommended dose of N: P: Kis 50:50:50 kg/ha)

\begin{tabular}{|c|c|c|c|c|c|}
\hline \multirow{2}{*}{$\begin{array}{c}\text { Treatment } \\
(\%)\end{array}$} & \multicolumn{5}{|c|}{ Fertilizer required(g) } \\
\cline { 2 - 6 } & Urea & Polyfeed & MultiK & Potash & Rajphos \\
& $(46: 0: 0)$ & $(19: 19: 19)$ & $(13: 0: 44)$ & $(0: 0: 50)$ & \\
\hline 120 & 9.6 & 22 & 36 & 8.4 & - \\
\hline 100 & 8.0 & 18 & 30 & 5.6 & - \\
\hline 80 & 6.4 & 14.5 & 24 & 7 & 9 \\
\hline Control & 8.0 & - & - & & - \\
\hline
\end{tabular}

Table.3 Number of leaves at different intervals of daysas influenced by 10 treatments

\begin{tabular}{|l|l|l|l|l|l|l|l|l|l|l|}
\hline & T1 & T2 & T3 & T4 & T5 & T6 & T7 & T8 & T9 & C \\
\hline 3Nov & 16 & 25 & 13 & 15 & 17 & 17 & 12 & 15 & 19 & 14 \\
\hline 10Nov & 36 & 56 & 34 & 33 & 45 & 34 & 33 & 31 & 42 & 26 \\
\hline 17Nov & 82 & 99 & 53 & 51 & 57 & 61 & 59 & 63 & 84 & 47 \\
\hline 24Nov & 108 & 159 & 105 & 82 & 94 & 100 & 88 & 72 & 111 & 96 \\
\hline 30Nov & 169 & 181 & 139 & 107 & 115 & 120 & 129 & 110 & 121 & 108 \\
\hline
\end{tabular}

Table.4 Stem girth $(\mathrm{cm})$ at different days as influenced by 10 treatments

\begin{tabular}{|l|l|l|l|l|l|l|l|l|l|l|}
\hline & T1 & T2 & T3 & T4 & T5 & T6 & T7 & T8 & T9 & C \\
\hline 3 Nov & 1.5 & 2.4 & 1.6 & 1.8 & 1.6 & 1.5 & 1.4 & 1.5 & 1.5 & 1.4 \\
\hline 10Nov & 3.7 & 3.9 & 3.4 & 3.2 & 3.3 & 3.1 & 3.1 & 3.2 & 3.9 & 3.3 \\
\hline 17Nov & 4.3 & 4.5 & 4.1 & 3.6 & 3.8 & 3.5 & 3.9 & 3.7 & 4.2 & 3.7 \\
\hline 24Nov & 5.0 & 5.1 & 4.6 & 4.0 & 4.1 & 4.3 & 4.5 & 3.9 & 4.3 & 4.0 \\
\hline 30Nov & 5.3 & 5.6 & 4.8 & 4.3 & 4.3 & 4.8 & 4.7 & 4.2 & 4.5 & 4.4 \\
\hline
\end{tabular}


Table.5 Yield (t/ha) of amaranthus as influenced by different treatments

\begin{tabular}{|l|l|l|l|l|l|l|l|l|l|l|}
\hline & T1 & T2 & T3 & T4 & T5 & T6 & T7 & T8 & T9 & C \\
\hline $1^{\text {st }}$ harvest & 0.56 & 0.60 & 0.46 & 0.31 & 0.15 & 0.19 & 0.28 & 0.43 & 0.26 & 0.00 \\
\hline $2^{\text {nd }}$ harvest & 1.39 & 1.65 & 1.30 & 1.24 & 1.30 & 0.77 & 1.11 & 1.12 & 1.14 & 0.65 \\
\hline $3^{\text {rd }}$ harvest & 1.11 & 1.25 & 1.20 & 0.55 & 0.88 & 1.02 & 0.87 & 0.69 & 1.03 & 0.78 \\
\hline $4^{\text {th }}$ harvest & 1.48 & 1.71 & 1.44 & 1.23 & 1.30 & 1.11 & 1.43 & 1.23 & 1.39 & 1.26 \\
\hline $5^{\text {th }}$ harvest & 1.30 & 1.63 & 1.34 & 1.37 & 1.20 & 1.30 & 1.39 & 1.37 & 1.39 & 1.26 \\
\hline $6^{\text {th }}$ harvest & 1.57 & 1.67 & 1.46 & 1.11 & 1.44 & 1.16 & 1.14 & 1.27 & 1.16 & 1.12 \\
\hline
\end{tabular}

The readings are shown in Table 4 . In the case of treatment $100 \%$ fertigation with $10 \mathrm{~cm}$ lateral depth, the number of leaves was also more as compared with the other treatments. The yield of treatment $100 \%$ fertigation with $10 \mathrm{~cm}$ lateral depth is obtained increased due to higher moister extraction. (Kant and Naoi, 1998). In treatment control, conventional practices were followed and yield per beds were observed minimum when compared to other treatments, fertigation with plastic mulching.

In statistical analysis, it was found that the treatments $120 \%$ fertigation level with $10 \mathrm{~cm}$ lateral depth and treatment $100 \%$ fertigation with $10 \mathrm{~cm}$ lateral depth were on par with treatment $80 \%$ fertigation with $10 \mathrm{~cm}$ lateral depth, but other treatments were significantly varies with these treatments. In treatment 80 $\%$ fertigation level with $10 \mathrm{~cm}$ lateral depth, it is possible to save $20 \%$ fertilizer. Hence, this study suggested that treatment is having $80 \%$ fertigation level with $10 \mathrm{~cm}$ lateral depth, is better because it needs less amount of fertilizer (Table 5).

In conclusion, accurate management of water, fertilizers and lateral depth with subsurface drip irrigation systems is the next step in producing high yield. Maximum yield was observed for the treatment which is of $10 \mathrm{~cm}$ lateral depth with $100 \%$ fertigation level. Statistically the treatment of $10 \mathrm{~cm}$ lateral depth with $100 \%$ fertigation level is on par with the treatment of $80 \%$ fertigation and 10 $\mathrm{cm}$ lateral depth. The study suggested that treatment of $80 \%$ fertigation and $10 \mathrm{~cm}$ lateral depth is better due to the fact that it gives higher crop yields with substantial saving in fertilizer usage. Hence, subsurface drip irrigation of $10 \mathrm{~cm}$ lateral depth with $80 \%$ fertigation level under plastic mulching for amaranthus is a good option as compared with conventional methods.

\section{References}

Hanson, B.R. 1994. Adheringto the rules of drip tape selection. Irrg. J. 44(50): 1013.

Hernandez, M.J.J., Bar-Yosef, B., and Kafkafi, U. 1991. Effectof surface and sub-surface drip fertigation on sweet corn rooting, uptake, drymatter production and yield. Irrg. Sci., 12: 153159.

Kant, R. and Naoi, T. 1998. Studies on the soil moisture extraction pattern (SMEP) of spring and summer pruned mulberry (Morns spp.) gardens. Indian J. Seric. 37(2): 167-170.

KAU (Kerala Agricultural University) 2005. Package of practices Recommendations: Crops. Kerala Agricultural University, Thrissur, 157p. Lamm, F.R., Manges, H.L., Stone, L.R., Khan, A.H., and Rogers, D.H. 1995. 
Water requirement of sub surface drip irrigated corn in Northwest Kansas. Trans. ASAE. 38(2): 441-448.

Oron, G., Malach, D.Y., Hoffman, Z., and Cibotaru, R. 1991. Sub surface micro irrigation with effluent. J. Irrg. Drain. Eng. Div. (ASCE). 117(1): 25-36.

Raina, J.N., Thakur, B.C., and Verma, M.L. 1999. Effect of drip irrigation and polyethylene mulch on yield, quality and water use efficiency of tomato. Indian J.Agric.Sci., 69(6): 430-433.

Reddy, S.G., Maheswari, U, K., and Reddy. Y, T. 2005. Effect of sub surface Vs surface drip irrigation on soil moisture distribution and growth of mango. Int. conference on Plasticulture and precision farming, pp 242.

\section{How to cite this article:}

Sariga, S., Jeena Joseph and Priya G. Nair. 2019. Optimization of Lateral Depth of Subsurface Drip Fertigation for Amaranthus. Int.J.Curr.Microbiol.App.Sci. 8(07): 515-520.

doi: https://doi.org/10.20546/ijcmas.2019.807.063 